\title{
Analiza in kritično ovrednotenje Xu Fuguanove interpretacije koncepta qiyun shengdong 气韵生动
}

\author{
Téa SERNELJ*
}

\section{Izvleček}

Članek obravnava Xu Fuguanovo analizo in interpretacijo koncepta qiyun shengdong 气韵 生动, ki velja za enega od najpomembnejših, najbolj temeljnih in hkrati najtežje dojemljivih konceptov v kitajski estetiki in umetnosti. Nastal je v obdobju Wei Jin (220-420 n. št.), ki je eno od najbolj ustvarjalnih in prelomnih obdobij na področju kitajske estetike in umetnosti. Njegova kompleksnost se izraža tako v literarnih delih, slikarstvu, kaligrafiji in glasbi, kot tudi v literarni teoriji ter teoriji slikarstva, pri čemer se $q i$ nanaša na zunanje značilnosti umetniškega dela, medtem ko izraža yun notranje značilnosti, ki so del človeške notranjosti oziroma človeškega duha, medtem ko shengdong pomeni manifestacijo, delovanje in zlitje obeh konceptov v umetniškem delu.

Avtorica najprej predstavi Xu Fuguanovo interpretacijo in jo prikaže v kontekstu sodobnih debat o kitajski estetiki. V nadaljevanju se osredotoči na njegovo filološko in historično analizo semantičnega ter filozofskega razvoja obravnavanega koncepta in na koncu poda kritično evalvacijo njegove študije $\mathrm{v}$ kontekstu ponovnega ovrednotenja osnov klasične kitajske estetike.

Ključne besede: Xu Fuguan, kitajska estetika, qiyun shengdong, chuanshen

\section{Analysis and Critical Evaluation of Xu Fuguan's Interpretation of the Concept qiyun shengdong 气韵生动}

\section{Abstract}

The present article deals with Xu Fuguan's analysis and interpretation of qiyun shengdong, which is regarded as one of the most significant and fundamental, as well as complex, concepts in Chinese aesthetics. It was developed in the Wei Jin period (220-420 $\mathrm{AD}$ ), which is considered the turning point in Chinese aesthetics and art. Its complexity is expressed in literary works, painting, calligraphy and music, as well as in literary and painting theory. In Xu's interpretation, the concept of $q i$ refers to the outward characteristics of the art work. The concept yun reflects the inner characteristics that are an integral part of the human spirit, while shengdong is merely a spontaneous and natural effect of the interaction between $q i$ and $y u n$.

Téa SERNELJ, Lektorica za sinologijo in doktorska študentka na Oddelku za azijske študije, Filozofske fakultete, Univerze v Ljubljani tea.sernelj[at]ff.uni-lj.si

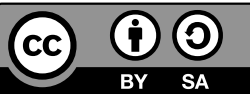


First, the author presents Xu Fuguan's interpretation and places it in the context of contemporary debates on Chinese aesthetics. The author then concentrates on Xu Fuguan's philological and historical analysis of the semantic and philosophical development of the concept, and at the end gives a critical evaluation of his study in the context of the re-evaluation of the basics of classical Chinese aesthetics.

Ključne besede: Xu Fuguan, Chinese aesthetics, qiyun shengdong, chuanshen

\section{Uvod}

Xu Fuguan 徐复观 (1903-1982) je predstavnik druge generacije filozofske struje Modernih konfucijancev (Xinrujia 新儒家), ki si je prizadevala za revitalizacijo konfucijanstva ter $\mathrm{z}$ njim celotne kitajske antične idejne tradicije in ju želela prilagoditi procesom kitajske modernizacije (Rošker 2014, 68).

Xu Fuguanov širok opus sega od političnih teorij do literarne kritike, pregleda in evalvacije kitajske antične filozofije, sociologije kulture, ter kitajske tradicionalne estetike. Ta članek obravnava Xu Fuguanovo analizo in interpretacijo koncepta qiyun shengdong, ki ga Xu razume kot najbolj temeljnega in esenčnega v tradicionalni kitajski estetiki. Bil je mnenja, da je za resnično dojetje esence kitajske umetnosti nujno razumevanje pomena koncepta qiyun shengdong. (Xu 2002, 84)

Članek je strukturiran tako, da sledi Xujevi shemi analize omenjenega koncepta, v kateri najprej obravnava posamezne koncepte znotraj qiyun shengdonga, torej qi in yun, qiyun in nazadnje shengdong. Zadnje poglavje je namenjeno evalvaciji $\mathrm{Xu}-$ jeve interpretacije qiyun shengdonga, v kateri se članek dotakne problema Xujeve teze o absolutni samoniklosti in ekskluzivnosti nekaterih značilnosti tradicionalne kitajske estetike.

$\mathrm{Xu}$ Fuguan je koncept qiyun shengdong podrobno obravnaval v svojem osrednjem delu Esenca duha kitajske umetnosti (Zhongguo yishujingshen 中国艺术精神), ki ga je napisal leta $1966 \mathrm{v}$ Tajbeju. V njem podrobno obravnava zgodovinski in idejno - filozofski razvoj kitajske tradicionalne umetnosti in estetike. $\mathrm{V}$ omenjenem delu Xu koncept qiyun shengdong podrobno analizira in interpretira. To delo, ki mimogrede še ni bilo prevedeno v nobenega od indoevropskih jezikov, je tudi temeljni vir tega članka.

Qiyun shengdong 气韵生动 se v zahodnih sinoloških in umetnostno teoretskih virih večinoma prevaja kot ritmična resonanca (rythmic resonance), resonanca duha (spirit resonance), ustvarjanje ritmične vitalnosti (create rythmic vitality), resonanca duha in gibanje življenja (spiritual resonance and life motion), pa tudi kot skladnost duha, ki ustvarja občutek življenja (spirit consonance engendering a sense of 
life) in podobno ${ }^{1}$. Xu Fuguan pa je kritičen do prevajanja yuna v smislu ritma ali resonance, ker meni, da ima yun dosti širši pojmovni spekter in je odvisen tudi od samega konteksta, v katerem se pojavlja.

Qiyun shengdong kot estetski koncept prvič zapiše Xie $\mathrm{He}^{2}$ sredi petega stoletja v delu Zapisi o antičnem slikarstvu (Gu huapin lu 古画品录 $)^{3}$ in sicer ga, kot bomo videli v nadaljevanju,postavi kot prvo in s tem tudi najpomembnejšo zakonitost slikarstva ${ }^{4}$. Sam koncept qiyun 气韵 pa se pojavi že dosti prej in sicer najprej $\mathrm{v}$ poeziji. Ta princip ostane v veljavi vse do začetka dvajsetega stoletja, ko so ga japonski in kitajski teoretiki začeli povezovati z idejo subjektivizma in subjektivnega izražanja, kot nekaj, kar je bilo nasprotno od forme ter $\mathrm{s}$ tem objektivnosti zahodnega realizma (Vampelj Suhadolnik 2013, 97-98).

Za razumevanje tega kompleksnega koncepta pa je osrednjega pomena tudi poznavanje družbenega ozadja in specifike obdobja, v katerem je nastal.

1 Qiyun shengdong je, kot bomo videli v nadaljevanju, zaradi njegovega širokega spektra pomenov zelo težko ustrezno prevesti v indoevropske jezike. Avtorica članka predlaga, da se koncept qiyun ohrani v izvirniku in se ga ne prevaja. Nekaj takih neprevedljivih konceptov se je že uveljavilo in se $\mathrm{v}$ zahodnih študijah uporablja v izvirniku, kot na primer koncepta dao 道 ali $q i$ 气.

2 Xie He 谢赫 (aktiven okoli leta 479-502 n. št., t.j. v obdobju Wei Jin 魏晉) je bil slikar in umetnostni kritik. Najbolj znan je po svoji definiciji šestih zakonitostih kitajskega slikarstva (buihua liufa 绘画六法), ki jih je potrebno upoštevati v kritičnem presojanju slikarskega dela. Teh šest zakonitosti je zapisal v predgovoru h knjigi Zapisi o antičnem slikarstvu (Gu huapin lu 古画品录), v kateri razvrsti umetniška dela sedemindvajsetih slikarjev $\mathrm{v}$ tri razrede glede na umetniško vrednost njihovih del. Vsak razred ima še tri podrazrede. Teh šest zakonov se je skozi čas spreminjalo in dobivalo drugačne in vselej nove pomene, vendar kljub temu v okviru kitajske estetike še danes veljajo za osnovni kriterij slikarske izobrazbe in presoje kritikov. Xie Hejevih šest zakonitosti je zapisanih v obliki paralelizmov, ki velja za tipično obliko zapisovanja v klasični kitajščini. Po Xu Fuguanu sta prvi dve pismenki jedro paralelizma, drugi dve pa se referirata na njegovo konkretno aplikacijo, ki se kaže v praksi. Samo prevajanje teh zakonitosti je še vedno predmet akademskih razprav. Razen prve zakonitosti, ki jo Xu Fuguan podrobno analizira in je jedro te raziskave, je prevod ostalih prevzet po interpretaciji Victorja H. Maira.

3 Xie He navede posamezne zakonitosti v obliki numeričnega naštevanja, kar naj bi bilo po mnenju Victorja H. Maira $(2004,100)$ prevzeto po indijski teoriji slikarstva Sadangi. (Z vprašanjem verodostojnosti te hipoteze se članek ukvarja v zadnjem poglavju): 一曰, 气韵生动是也: qiyun shengdong (qiyun je to, kar naredi delo živo), 二曰, 骨法用笔是也: gufa yongbi (gu se pravzaprav referira na $q i, f a$ je metoda in yongbi pomeni uporaba čopiča, torej tehnika skozi katero se reprezentira $q i)$; 三曰, 应物象行是也: yingwu xiangxing shi ye (ujemanje objektov se doseže skozi reprezentacijo oblik); 四曰, 随类赋彩是也: suilei fucai (glede na vrsto (objektov, oblik) se nanaša barve); 五曰, 经 营位置是也: jingying weizhi (postavitev in pozicioniranje (objektov) skozi razporeditev in samo zgradbo); 六曰, 传移模写是也: chuanyi moxie shi ye (prenos poustvarjanje in kopiranje (starih mojstrov) skozi prenos modela (ibid.).

4 Xie Hejevih šest zakonitosti je kljub temu, da je bila njegova teorija slikarstva takrat še na nek način v embrionalni fazi, kasneje postala koncizen, jasen in celovit sistem, ki je po Xujevem mnenju narejen mojstrsko (ibid.). 


\section{Obdobje Wei Jin in rojstvo klasične kitajske estetike}

Obdobje Wei Jin (220-420 n.št.) velja za enega najbolj plodnih in ustvarjalnih obdobij na področju filozofije, umetnosti in psihologije v kitajski zgodovini. Kulturno idejnemu preboju so botrovale velike družbeno politične spremembe, ki so nastale zaradi razpršenosti oblasti in vpadov nomadskih ljudstev iz severa (zlasti Hunov in kasneje ljudstva Xianbei), ki so začeli zavojevati sever Kitajske, kar je privedlo do množične migracije Han kitajskega prebivalstva iz visoko razvitega severa na sorazmerno nerazviti jug. Ekonomsko in družbeno politično oblast so prevzeli bogati aristokratski klani (zlasti klana Cao in Sima), ki so se (poleg izvajanja nenehnih političnih intrig in boja za prevlado) navduševali nad poezijo, kaligrafijo, pitjem vina in daoistično filozofijo, torej nad vsem, $\mathrm{k}$ čimer so se v tistih turbulentnih časih zatekali filozofi in umetniki ${ }^{5}$.

To je privedlo do zatona študija konfucijanskih klasikov, ki so prevladovali v dinastiji Han, pri čemer moramo upoštevati dejstvo, da konfucianizem v dinastiji Han nima kaj dosti opraviti z izvornim konfucijanskim naukom, saj se je konfucijanstvo v dinastiji Han zlilo $\mathrm{z}$ legalizmom, kar poznamo kot prvo reformo konfucijanstva, ki je privedla do konfucianizma kot državne doktrine. Po drugi strani pa so zatonu konfucijanstva botrovala tudi ljudstva na severu, ki niso nadaljevala s sistemom državnih izpitov, čigar zametke je postavil Han Wudi 汉武帝 v Zahodnem Hanu. Posledično so uradniki izgubljali možnost pridobivanja visokih nazivov, hkrati pa so se vedno bolj začeli usmerjati v umetnost, slikarstvo in literaturo.

Kot odgovor na rigidnost hanskega konfucianizma in zavrnitev njegovih togih moralnih principov in standardov nastane neodaoizem, ki ga poznamo pod imenom Šola misterijev (Xuanxue 玄学), katere glavna predstavnika sta bila filozof Wang Bi 王弱 in He Yan 何晏. Vsebina šole Xuanxue je v glavnem temeljila na filozofiji Laozija in Zhuangzija, vključevala pa je tudi nekatere konfucijanske elemente. Filozofske debate, v katere je bila vključena intelektualna elita in aristokratska smetana, so znane pod imenom Čisti pogovori (qingtan 清谈). Ukvarjali so se $\mathrm{z}$ iskanjem nove morale, metafiziko in logiko. Čistim pogovorom so prisostvovali tudi modreci iz bambusovega gozdička. (Rošker 2005, 86)

5 Iz tega obdobja poznamo znamenitih Sedem modrecev iz bambusovega gaja (Zhulin qi xian 竹林 七仙) med katerimi sta najbolj znana Ji Kang 嵇康 in Ruan Ji 阮籍. Kljub temu, da je imela večina od njih možnost in priložnost delovanja na političnem nivoju, so se zaradi negotove politične situacije in izprijenosti ter koruptivnosti aristokratskih klanov, odločili za odmik v samoto, kjer so uživali $\mathrm{v}$ ustvarjanju poezije, glasbe, kaligrafije in filozofije. Političnim temam so se zavestno popolnoma odpovedali, predvsem zato, da si s kritiziranjem politične situacije ne bi ogrozili svobodnega življenja in tvegali morebitnega obglavljenja (Ji Kang na primer se temu na žalost ni mogel izogniti). To, k čemur so težili, je bilo uživanje življenja na najbolj spontan možen način, kar je znano kot Zhuangzijev xiaoyao you (svobodno in lahkotno lebdenje). 
Po Li Zehouju lahko o obdobju Wei Jin govorimo kot o prebujenju človeka oziroma ljudi (ren de juexing 人的觉醒). ( $\mathrm{Li} 2003$, 80) Za razliko od togega poudarjanja starih tradicij, običajev, časti in moralne integritete, ki je bilo značilno za dinastijo Han, pride $\mathrm{v}$ Wei Jinu v ospredje človek in njegova osebnost. V umetnosti in literaturi obdobja Wei Jin so v središču zanimanja vrednost človeškega življenja in izražanje človeških čustev ter občutij; njegov značaj in njegov duh v smislu neomejenih potencialnih možnosti postane središče političnih, družbenih in kulturnih razprav. (ibid.) Kakšen je bil odnos do življenja, se najbolj jasno in neposredno kaže skozi poezijo tistega obdobja. Osrednje teme v poeziji so bile zavedanje smrtnosti, minljivosti in kratkosti življenja, žalost in obžalovanje, strah pred prezgodnjo smrtjo, obenem pa čaščenje in uživanje življenja dokler le-to traja. Estetski lepotni ideal vladajoče elite je bil v izrazu človekove modrosti in vzvišenega značaja skozi impresivni zunanji izgled.

Novonastali slog Wei Jina je bil torej zgrajen na zavedanju minljivosti življenja, predajanju užitkom in poglabljanju v filozofske razprave. Te se v prvi vrsti niso več toliko ukvarjale s človekovim opazovanjem narave kot raziskovanja zunanjega sveta (waizaishijiede tansuo 外在世界的探索), temveč je bil poudarek na ontologiji v smislu iskanja notranje substance (neizai shitide chuiqiu 内在实体的追 求), pri čemer je bilo bogastvo in raznolikost stvarnosti moč doseči samo takrat, ko so bile za to izpolnjene vse potencialne možnosti. To je pomenilo pridobiti vzvišeni duh, ki je primerljiv z duhom modrecev oziroma plemenitnikov, a vendar hkrati ohraniti človeške žalosti in radosti. Osredotočanje na človeško notranjost, ki ima neomejene možnosti namesto na zunanji svet, je bil hkrati kriterij lepote $\mathrm{v}$ umetnosti in srčika filozofije. Ta je v tem obdobju temeljila na Wang Bijevi ontologiji binarne kategorije benmo 本末 (korenina in veje), pri kateri je prvo izvor in hkrati vir (dao) vseh stvari (wanwu 万物), slednje pa njihov konkretni (fizični) izraz. Wangova ontologija je bila osnovana na konceptu odsotnosti (yi wu wei ben 以无为本) (ibid. 84-86), ki pomeni:

najizvornejši dao, ki je enak naravi, brezskrajnosti, novorojenemu, preprostosti in resnici. Ampak zakaj se imenuje "odsotnost"? Zato, ker je vse to - namreč dao, narava, preprostost, resnica - nepoimenljivo. Kakor hitro se pojavi ime, se dao izgubi. (Rošker 2005, 207)

Wang Bijeva ontologija je močno vplivala na umetnost in estetiko obdobja Wei Jin. Po Xu Fuguanu in Li Zehouju se temeljni koncepti kitajske estetike, kot tudi literarna teorija in slikarstvo izgradijo ravno v obdobju Wei Jin in ne prej. 


\section{Osrednji koncepti v estetiki obdobja Wei Jin}

Osredotočenost na natančne upodobitve zunanjega okolja, vedenja ter naravnanosti ljudi in pomembnih dogodkov je bila značilnost slikarstva in literature v dinastiji Han. V obdobju Wei Jin pa začneta cveteti tudi lirična poezija in figuralika. Osrednji koncepti v estetiki in umetnosti obdobja Wei Jin so

- izraz duha skozi obliko (yi xing xie shen 以形写神),

- qiyun shengdong 气韵生动 (qiyun naredi umetniško delo živo) in

- besede ne morejo v celoti posredovati pomena (yan bu jin yi 言不尽意).

Koncept izraz duha skozi obliko $\mathrm{v}$ tradicionalno kitajsko estetiko in umetnost vpelje Gu Kaizhi, o katerem bomo spregovorili v nadaljevanju, koncept besede ne morejo v celoti posredovati pomena pa izvira iz Wang Bijeve ontologije.

V nadaljevanju članka se bomo podrobno ukvarjali s Xu Fuguanovo interpretacijo teh osrednjih konceptov, s poudarkom na konceptu qiyun shengdonga, za uvod pa si pa si poglejmo, kako te osrednje koncepte definira Li Zehou':

所谓气韵生动就是要求绘画生动地表现出人的内在精神气质，格调 风度, 而不在外在环境, 事件, 形状, 姿态的如何铺张描述.

Zahteva tako imenovanega qiyun shengdonga je v tem, da slika živo izrazi človeški notranji značaj in stanje duha, umetniški stil kot tudi moralne lastnosti in držo ustvarjalca, ki pa se ne ne kaže skozi razkošno opisovanje oziroma upodobitve zunanjega okolja, okoliščin, dogodkov, obliki in drži (Li 2003, 86).

Izražanje duha skozi obliko (yi xing xie shen 以形写神) ima podoben pomen. Gre za izražanje človeške notranjosti, značaja, stanja duha, ki se kaže skozi telesno (zunanjo) obliko. Kot pravi Gu Kaizhi 顾恺之 (približno 345-406), eden najbolj cenjenih in najbolj slavnih slikarjev v dinastiji Vzhodni Jin:

四体妍虫本无关于妙处, 传神写照正在阿堵中.

Ali so štiri okončine (deli telesa) lepi ali ne, to ni merilo. Pomembna je upodobitev duha, ki se kaže skoznje.

Kot pravi Li Zehou, so oči ogledalo duše in ravno to je tisto, kar so si umetniki prizadevali upodobiti. To pomeni, da so sama oblika telesa ali človekova dejanja pravzaprav sekundarna in podrejena izrazu notranjega duha. (ibid., 87)

$6 \quad$ Li Zehou je eden od glavnih in osrednjih teoretikov kitajske estetike. Njegova dela so prevedena $\mathrm{v}$ angleški in nemški jezik, zato je dobro poznan tudi zahodni publiki (gl. Rošker 2017a, 1). Xu Fuguanova dela zaenkrat še niso prevedena v indoevropske jezike. 
Pri estetskem kriteriju in konceptu besede ne morejo v celoti posredovati pomena (yan bu jin yi 言不尽意) v literarni umetnosti gre po mnenju Li Zehouja za izražanje pomena, ki ga konceptualne besede in fraze ne morejo $\mathrm{v}$ celoti posredovati. Ta koncept v osnovi izraža načela filozofske šole Xuanxue. Iz Wang Bijevih komentarjev h Knjigi premen, vidimo, da so tako besede kot podobe orodja prenosa duha, ki so sama po sebi omejena. Kar je kljub tem omejitvam pomembno, je to, da si prizadevamo izraziti neomejenost esence (benti 本体) stvari:

\section{尽意莫若象, 尽象莫若言, 言者所以明象,得象忘言, 象者所以以存意, 得意忘象.}

Nič ne more bolj v celoti izraziti pomena kot podoba. Nič ne more bolj v celoti izraziti podobe kot besede. Besede so tiste, ki razjasnijo podobo. Ko se ta zgodi, se pozabijo besede. Podoba je tisto, kjer obstaja pomen. Ko je dosežen pomen, se podoba pozabi (Wang Bi v Li 2003, 87).

Po Liju gre pri vseh treh konceptih bodisi za izraz notranjega značaja, ki je lastna samo modrim (plemenitnikom), ki je neomejena, neizčrpna in onkraj dosega navadnih ljudi, bodisi za izražanje transcendentnega doživetja vsakdana preko različnih čustev, ki so skupna vsem ljudem. (ibid.)

\section{Xu Fuguanova analiza in interpretacija koncepta qiyun shengdong}

Xie Hejev koncept qiyun shengdong je najpomembnejši in najtežje razumljiv koncept $\mathrm{v}$ njegovi teoriji slikarstva, ki jo je natančno definiral v predgovoru $\mathrm{h}$ knjigi Zapisi o antičnem slikarstou (Gu huapin lu 古画品录). V njej poda šest zakonitosti slikarstva, katerim je potrebno slediti in jih dosledno upoštevati, v kolikor želi slikar ali slikarka (slednjih takrat zaradi neenakega položaja žensk v družbi seveda ni bilo ravno v izobilju) doseči vrhunsko dovršeno umetniško delo. Xie He tako velja za enega prvih umetnostnih kritikov na področju slikarstva.

Xu Fuguan pa v svoji obravnavi izpostavi, da je pred Xie Hejem qiyun shengdong omenjal že znameniti slikar Gu Kaizhi (344 n.št. do 406 n. št.), čeravno je pri tem uporabil drugo izrazoslovje. $\mathrm{Gu}$ je za temeljno zakonitost oziroma glavni kriterij slikarstva postavil prenos duha (chuanshen 传神). Tako pravi, da je v umetnosti slikarstva ključnega pomena avtorjevo portretiranje prenosa duha (chuanshen xiezhao 传神写照) in njegova upodobitev skozi zunanjo obliko (yixing xieshen 以 形写7神). Tovrstna upodobitev (xiezhao 写照) je torej to, kar lahko vidimo, duh

7 V tradicionalnem kitajskem slikarstvu se je pogosto namesto glagola slikati (huibua 绘画) uporabljal glagol pisati, opisati ( $x i e$ 写画) zato, ker se je slikarstvo kot umetniška zvrst pravzaprav razvilo iz kaligrafije (Xu 2002, 85). 
pa je tisto, česar ne moremo videti, vendar ga lahko občutimo ${ }^{8}$. Duh (shen 神) je esenca človeka in posebna značilnost vsakega posameznika. Duh oziroma esenca ljudi in medčloveških odnosov se tako izraža skozi slikarstvo (Xu 2002, 92). Po $\mathrm{Xu}$ Fuguanu gre pri tem za konceptualni premik v estetiki, ki se je zgodil ravno v obdobju Wei Jin.

$\mathrm{V}$ tem obdobju se je slikarstvo namreč osredotočalo na upodabljanje ljudi, pri čemer se je zlasti razvila figuralika, v kateri so ljudje objekt slikarstva. V obdobju Wei Jin se skozi reprezentacijo ljudi zrcali prepoznanje lepote človeškega značaja in medčloveških odnosov. Pri tem ne gre za upodabljanje človeških fizičnih lastnosti, temveč bolj za upodobitev človeškega duha $\left(\operatorname{shen}^{9}\right)$. Tovrstna tendenca se ne kaže zgolj v slikarstvu, temveč v vseh umetniških zvrsteh.

Pri teh elementih je šlo za popolnoma nove usmeritve, kajti če opazujemo kiparstvo in slikarstvo dinastije Han (206 pr. n. št. do 220) vidimo, da je takrat slikarjem v glavnem šlo za upodabljanje zgodb iz kitajskih antičnih del in slavnih osebnosti. To se je seveda delno preneslo tudi v obdobje Wei Jin, ampak s to razliko, da so se pri osebah, ki so jih upodabljali, slikarji v glavnem osredotočali na prikazovanje njihovega duha, skozi katerega sta se izražala njihova notranja vrednost in pomen. Reprezentacija duha je torej glavno vodilo in kriterij umetnosti obdobja Wei Jin. Ta predstavlja izjemen napredek $v$ tradicionalni kitajski umetnosti, ki je še posebej viden na področju slikarstva ${ }^{10}$. Tisto, kar tovrstno transformacijo (t.j. prenos človeškega duha v sliko) omogoča, pa je po Xuju ravno qiyun shengdong (Xu 2002, 91).

Prenos duha (chuanshen 传神) je torej temelj figuralnega slikarstva na Kitajskem, ki se je od dinastije Wei Jin dalje prenašal naprej. Xu meni, da je pomen $\mathrm{Gu}$ Kaizhijevega prenosa duha še bolj jasno in natančneje prikazan v Xie Hejevem opisu koncepta qiyun shengdong. Vse to, kar je $\mathrm{Gu}$ imenoval chuanshen pa tudi vse druge izraze, povezane $\mathrm{z}$ duhom, kot so npr. 神气 shenqi (vitalnost duha), 神明 shenming (jasnost duha), 神灵 shenling (božanskost duha) itd., je Xie He združil $\mathrm{v}$ enega in ga poimenoval qiyun shengdong.

8 To, s pomočjo česar lahko občutimo ta notranji duh, ki se v podobi latentno manifestira, je qiyun shengdong, četudi ga Gu kot takega še ni eksplicitno imenoval.

9 Izraz shen se v angleščno prevaja kot spirit (duh). Problem tovrstnega prevoda je njegova religiozna konotacija, ki pa v kitajski idejni tradiciji (zlasti v filozofiji in estetiki) ne obstaja. Če definiramo duha (in duhovnost) kot je to posrečeno storil Ewert Cousins, potem lahko po mojem mnenju brez težav sprejmemo duh kot ustrezen prevod besede oziroma pojma shen. Takole pravi: "Spirituality can be described as the inner dimension of the person called by certain traditions 'the spirit'. This spiritual core is the deepest center of the person. It is here that a person is open to the transcendent dimension; it is here that the person experiences ultimate reality." (Wu 2002, 441).

10 Zato ni slučaj, da Xu poudarja $(2002,91)$, da se slikarstvo kot samostojna in dovršena umetniška zvrst ne začne prej kot v obdobju Wei Jin. 
Qiyun shengdong je dejansko konkretiziranje in preciziranje ideje duha in zato, pravi $\mathrm{Xu}$, je vreden natančne analize. Xu Fuguan se te natančne analize loti tako, da ločeno obravnava posamezne koncepte, ki tvorijo frazo qiyun shengdong. Pri tem gre v prvi vrsti za dva koncepta, tj. za koncept $q i$ in koncept yun, ki imata vsak svoj pomen, vendar sta, kot bomo videli v nadaljevanju neločljivo povezana znotraj umetniškega dela. V naslednjih podpoglavjih bomo na temelju metode, ki jo je uporabil Xu Fuguan kritično ovrednotili njegovo analizo posameznih konceptov znotraj besedne zveze qiyun shengdong.

\section{Qi kot filozofski in etični koncept}

$Q_{i}$ 气 je eden od najbolj kompleksnih konceptov $\mathrm{v}$ kitajski idejni tradiciji in filozofiji. V indoevropskih jezikih obstaja cela paleta različnih prevodov tega pojma; najpogostejši med njimi so zrak, dih, vitalnost, izvir življenja, energija, pa tudi materija, snovnost ipd.

Že od najzgodnejših filozofskih diskurzov na Kitajskem, sodi qi k najbolj temeljnim kategorijam razumevanja stvarnosti (Rošker 2017b). Izvorno so antični kitajski filozofi qi razumevali kot utelešenje naravnih pojavov.

Šest vrst qija neba so: yin, yang, veter, dež, tema in svetloba, ti pa so v povezavi s petimi elementi zemlje: kovina, les, voda, ogenj in zemlja. Izmed šestih qijer neba, dež in veter prinašata rojstvo vseh stvari oz. bitij. $Q i$ svetlobe in teme prikazuje spremembo dneva in noči kot ene od zakonitosti narave; binarni kategoriji yin in yang, pa sta pravzaprav značaj vseh zemeljskih oziroma vremenskih pojavov. Poleg ustvarjanja vseh naravnih pojavov, $q i$ neba in zemlje ustvari tudi človeka. (Wong 1989, 46). To definicijo najdemo na primer tudi v poglavju Neiye 内业 pomemb-

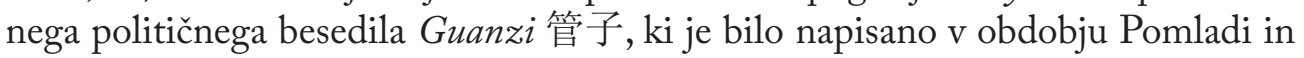
jeseni, tj. okoli $770-476$ pr. n. št.:

\section{凡人之生也, 天出其精, 地出其形, 合此以为人}

Vsi ljudje nastanejo tako, da jim prispeva nebo svojo esenco, zemlja pa fizično obliko. Ko se oboje združi, nastane človek (Guanzi s.d. Neiye: 7).

Ta esenca (jing 精) je kasneje definirana kot esenca qija (jingzhe, qizhijing ye 精者, 气之精也). Koncept qi kot jing, torej kot esenca oz. izvor življenja, je tako postal neke vrste ontološka osnova obstoja:

有气则生, 无气则死

Stvari so žive, dokler imajo qi in čim ga izgubijo, so mrtve (ibid. Shu yan: 1). 
Kozmični qi torej ustvarja vse bivajoče. Ker človeku (in drugim živim bitjem) omogoča preživetje na zemlji, na katerega se mora človek odzvati tako, da se obnaša krepostno. V nasprotnem primeru človek poruši ravnovesje, kar pripelje do kaosa:

夫天地之气, 不矢其序, 若过其序, 民乱之也.

Če človek ne deluje v skladu s qijem neba in zemlje, je med ljudmi kaos (Guoyu v Wong 1989, 47).

Qi kot kozmološko ontološka entiteta je torej dobil moralni značaj, ki je imel $\mathrm{v}$ konfucijanstvu osrednji pomen. Zaradi teorije yinyanga in petih faz (yinyang wuxing 阴阳五行), ki je bila v ospredju v času dinastije Han, mnogo ljudi dojema $q i$ kot metafizični koncept. Vemo pa, da se koncept qi v smislu »nege qija (yangqi 养气)《 začne z Mencijem (379 pr. n. št.-289 pr. n. št.) in kaže na povezanost s fizičnim, s telesnim, in ga zato lahko imenujemo tudi fizična življenjska sila (shenglide shengmingli 生理地生命力). (Xu 2002, 94) $)^{11}$

A Mencij je hkrati izpostavil, da so za nego qija v človeškem telesu nujne tudi moralne kreposti, predvsem pravičnost in iskrenost, ki potem recipročno delujejo na delovanje neba, ki se kaže v umirjenih in stabilnih družbenih razmerah (Wong $1989,48)$.

Ozaveščenost in nega qija je bila seveda osrednjega pomena tudi v daoističnih telesnih in meditativnih praksah, kot so qigong 气功, taiji quan 太极拳 in zuowang 坐忘 ${ }^{12}$. Kot esenca življenja je $q i$ torej tesno povezan s telesnimi čuti in percepcijo. $\mathrm{V}$ tem smislu pa že seže tudi na področje kitajske estetike:

天有六气, 降生五味, 发为五色, 征为五声.

Nebo ima šest qijer, ti ustvarijo pet okusov, se izrazijo v petih barvah in potrdijo v petih tonih (Zuo zhuan s.d. v Wong 1989, 48).

Kot smo videli zgoraj, se $q i$ kot moralni koncept pojavi v filozofiji Mencija. Kot temeljni estetski koncept pa se pojavi v obdobju Wei Jin. Okusi, barve in zvoki in drugi elementi so transmutacije qija. Posredovanje qija in še posebej njegove esence, ki se kaže skozi delovanje yina in yanga, je postalo osrednji in najbolj temeljni namen v kitajski umetnosti (Wong 1989, 45).

11 Kot protipol dinamični strukturi $l i$ 理 se pojavlja v vlogi snovnosti tudi v okviru neokonfucijanstva dinastije Song.

12 Razlika med daoističnimi in Mencijevimi oz. konfucijanskimi tehnikami izpopolnjevanja osebnosti je $\mathrm{v}$ tem, da je bil cilj in namen prve doseči harmonično zlitje človeka $z$ daotom oz. naravo, namen druge pa je bil predvsem kultivacija moralnega značaja. 


\section{Qi kot estetski koncept}

$Q i$ se kot estetski koncept najprej pojavi v povezavi $\mathrm{z}$ literaturo. Kot prvi ga v tem kontekstu omeni Cao Pi 曹丕 (187-226) v svojem delu Razprave o literaturi ( $D_{i-}$ anlun lunwen 典论伦文):

文以气为主, 气之清浊有体, 不可力强而致.

$\mathrm{V}$ literaturi je qi glavni. Lahko je jasen in čist ali medel in kalen in se ga ne da doseči na silo (Cao Pi s.d. 4).

Po Xuju je qiv literarni umetnosti povezan $z$ delovanjem fizičnega v smislu ustvarjalnega potenciala, ki se transformira $\mathrm{v}$ umetniški produkt. Vse metafizične konotacije koncepta $q i$ so v tem kontekstu zanj odveč, kajti človeške ideje, čustva, in domišljija se rodijo v qiju in se šele potem začnejo izražati v umetniških delih. (Xu 2002, 95)

$Q i$, ki se v literarni umetnosti izraža skozi ideje, čustva in domišljijo, so pravzaprav nakopičen qi. Zato se individualni značaj, ki oblikuje posameznikovo umetnost določa skozi qi. Prenos duha (chuanshen), o katerem smo govorili v prejšnjem poglavju, se dejansko kaže skozi qi. $Q i$, ki se sublimira in zliva z duhom (shen), postane umetniški $q i$. Tako se skozi delovanje qija jasno kaže ustvarjalčevo notranje življenje navzven in to je ena najzanimivejših posebnosti kitajske literarno umetnostne teorije ter kitajske umetnosti nasploh. Povezanost qija $\mathrm{z}$ duhom postane tako entiteta oziroma enotnost. Zato so v tistem času zelo pogosto uporabljali izraz shenqi $i$ 神气 (duh qija).

Po drugi strani pa qi reprezentira tudi ustvarjalčev moralni značaj (pinge 品格) kot vzvišeno kvaliteto (qigai 气概), ki ustvarja ozadje umetniškega dela. V obdobju Wei Jin so qi v kontekstu umetnosti pogosto imenovali tudi moč qija (qili 气力) ali njegov momentum (qishi 气势). Pogosto pa so namesto qija v tem pomenu uporabljali tudi besedo gu 骨 (skelet, okvir), ki ga je pravzaprav simbolizirala. (ibid., 95)

Iz zgoraj navedenega vidimo, da se qi kot estetski koncept nanaša na človeški ustvarjalni potencial, ki je osnova umetniškega ustvarjanja. Ta potencial je tesno povezan s človeškimi čustvi, občutji in domišljijo, ki nastajajo skozi percepcijo in dojemanje sveta preko čutnih organov, in ki v estetiki obdobja Wei Jin odsevajo lepoto človeške notranjosti. Reprezentacija le-tega je bila, kot smo videli v uvodu, temeljni cilj in estetski kriterij v umetnosti tega obdobja.

\section{Osnovne pomenske konotacije pojma yun}

Beseda yun 韵 se je prvič pojavila v dinastiji Han. Najdemo jo v najstarejšem kitajskem etimološkem slovarju Shuowen jiezi iz prvega stoletja našega štetja, kjer 
je definirana kot harmonija oziroma harmoničnost: 韵, 和也 ${ }^{13}$. Enako definicijo najdemo tudi v enciklopediji Guangya 广雅 iz obdobja Wei v tretjem stoletju. Po mnenju Xu Fuguana je torej v tistem obdobju pismenko za harmonijo (he 和) nadomestila pismenka yun 韵 (Xu 2002, 94).

Tako kot qi ima tudi yun $\mathrm{v}$ različnih kontekstih in različnih umetniških zvrsteh različen pomen. $V$ fonetiki (yinyunxue 音韵学) pomeni ton. $V$ poeziji pomeni rimo. $\mathrm{V}$ slikarstvu je yun najpogosteje prevajan kot ritem ali ritmična resonanca. Kot smo omenili zgoraj, ta prevod po mnenju Xuja ni ustrezen, ker ne pokriva vseh njegovih pomenov. Tudi Wong $(1989,57)$ meni, da v glasbeni teoriji prevod besede yun kot ritmična resonanca ni neoporečen. $V$ estetiki in filozofiji ima yun še precej globlji in bolj kompleksen pomen, zato je nujno potrebno podrobneje raziskati tako njegov izvorni pomen, kot tudi njegove različne konotacije v različnih kontekstih. (ibid.)

Kot navede Wong (ibid.) se je yun v kitajski tradiciji tesno povezoval predvsem z glasbo. Najzgodnejši pojav te besede zasledimo v Cao Zhijevem 曹植 (192-232) Eseju belega žerjava (Baihe fu 白鹤赋):

聆雅琴之清韵.

Poslušam jasen in čisti yun prefinjenega qina ${ }^{14}$ (Cao Zhi v Wong 1989, 57).

Prav tako ga zasledimo v Ji Kangovem (224-263 n.št.) Poetičnem eseju o qinu (Qin$f u$ 琴赋), kjer pravi (Wong 1989, 57)

改韵易调,奇弄乃发.

Iz spremembe yuna in melodije $\mathrm{v}$ glasbi, se pojavi čudovito občutje.

Četudi se je yun sprva uporabljal v pomenu ritma v glasbi, je kaj kmalu besedo za ritem nadomestila pismenka $l \ddot{u}$ 律. Od takrat dalje se je pismenka yun zelo redko uporabljala v povezavi z glasbo. (Xu 2002, 98)

V glasbi pomeni yun glasbeni izraz oziroma melodično gibanje. Kasneje so yun prevzeli v literarnih in fonetičnih kontekstih. Iz fonetičnega gledišča je yun bolj ali manj definiran kot ton. $V$ poeziji oziroma $\mathrm{v}$ poetičnih esejih, postane pomen yuna bolj jasen, in če pogledamo Liu Xiejevo 刘劦思 definicijo yuna, zapisanega $\mathrm{v}$ njegovem delu Srčna zavest literature in rezbarjenje zmaja (Wenxin diaolong 文心 雕龙), ki velja za največje delo o literarni estetiki, napisano v 6. st., kjer pravi:

13 Wong (1989) v svoji dizertaciji z naslovom The manifestation of Chinese Philosophy and Aesthetics in the Performance of the pipa Music napačno navede, da besede yun ni bilo zapisane v slovarju Shuowen jiezi (Wong 1989, 57).

14 Kitajsko brenkalo podobno citram. 


\section{異音相從謂之和，同声相应谓之韵.}

Zaporedje različnih tonov imenujemo harmonija, zaporedje enakih zvokov pa yun (Liu Xie s.d.: VII, Shenglü: 2).

Wong $(1989,58)$ opozarja, da se yun tukaj nanaša na rimo in ne na ritem. Xu meni, da ne glede na to, ali uporabljamo yun v glasbi ali literaturi, ima v obeh primerih prizvok pomena tiaohe 调和, ki pomeni biti v harmonični proporciji. Eden izmed pomenov yuna je po Xuju harmonični zvok oziroma duh zvoka, v nobenem primeru pa se pomen yuna ne more razumeti kot ritmičnost. (Xu 2002, 99)

Wong $(1989,62)$ pa konkretneje opredeli tudi pomen yuna $\mathrm{v}$ glasbi, ki tam pravzaprav pomeni umetnost obvladanja modulacije tona, kateri ustvari nek presežek občutek (yunwei 韵味).

$\mathrm{V}$ slikarstvu pa nastopa yun $\mathrm{v}$ glavnem $\mathrm{v}$ povezavi s qijem, zato ga je $\mathrm{v}$ kontekstu slikarstva težko obravnavati ločeno od njega. Koncept qiyun si bomo podrobneje ogledali v naslednjem podpoglavju.

\section{Yun kot estetski koncept}

Kot estetski koncept se yun $\mathrm{v}$ prvi vrsti nanaša na izraz človeškega značaja in duha, kakršen se razkriva v umetniškem delu. Xu Fuguan ga definira tudi kot prepoznanje medčloveških odnosov (renlun jianshi 人伦鉴识), ki je bil v filozofiji Xuanxue razumljen kot odraz samo-kultivacije. V tem kontekstu namreč izraža enotnost duha in oblike (shenxing heyi 神形合一), ki se reprezentira navzven, tj. skozi podobe v umetniških delih. Le-to so v tistem času imenovali atmosfera oz. splošno občutje (fengqi 风气).

Ta izraz yuna je viden tudi v naravi:

\section{自然有雅韵}

Eleganco in vzvišenost yuna je najti v naravi (Xu 2002, 100).

Xujeva interpretacija yuna kot koncepta, ki izraža prepoznanje človeških odnosov (oziroma njihove etike) se nanaša na preslikavo harmoničnosti in vzajemnosti zvokov na medčloveške odnose (ibid., 101). Tako pravi, da je yun v glasbi in literaturi dejansko ustvarjen skozi harmonično enotnost različnih zvokov. Ta različnost zvokov pa je $\mathrm{v}$ glasbi vrhunske kakovosti presežena in tako nastane takim. enotni zvok. To vrsto enotnosti lahko izkusimo, po drugi strani pa to ni stvar, na katero bi lahko konkretno pokazali. Zato lahko rečemo, da je yun duh zvoka (ibid.) To 
si lahko predstavljamo s pomočjo analogije človeka: tudi ljudje po eni strani ne morejo zapustiti svoje oblike ali svojega značaja, po drugi pa lahko vendarle transcendirajo svojega duha $\mathrm{v}$ harmonično enotnost s soljudmi.

$\mathrm{Xu}$ Fuguan je torej prepričan, da nosi yun v sebi pomen lepote posameznikovega značaja in njegovih občutij, vendar seveda samo pod pogojem, da so ta harmonična in temeljijo na ponotranjenju konfucijanske etike. $\mathrm{V}$ tem smislu Xu koncepta yun ne povezuje z zvokom. Ta vrsta lepote se kaže navzven, tj. skozi človeški izraz. Tovrstni yun, v katerem sta zlita duh in zunanjost, se izrazi na slikah in prav v tem je osrednji pomen yuna znotraj koncepta qiyun. (Xu 2002,102)

Kot estetski koncept se na prvi pogled zdi, da je yun odvisen od qija. Qi je življenjska oziroma kreativna sila, ki se manifestira skozi celotno umetniško delo, medtem ko se yun kaže v fragmentih posameznih podob ali izrazov. Zato je bil koncept $q i$ osrednji kriterij v vrednotenju umetniškega dela, yun pa bolj izraz njegove popolnosti.

Podobno definicijo obeh konceptov znotraj tradicionalne kitajske estetike poda Wang Qingwei (2004), ko pravi, da je qi je izvor vseh stvari in življenja univerzuma in osnovna ideja samega univerzuma, življenja in umetnosti v tradicionalni kitajski kulturi. Prezentacija in izraz qija pa je dosežena skozi yun. Značilnost yuna je, da ni opis ali upodobitev zunanje oblike, temveč izraža notranjo naravo človeka oziroma stanje duha, ki prikaže stvari onkraj njihove podobe in je kot tak odvisen je od stanja duha subjekta. (Wang 2004)

Kasneje so umetniki iz dinastije Song yun razvili v globlji koncept in ga pojmovali kot najvišjo lepoto, ki jo umetnik (ali umetnica) lahko doseže (Wong 1989, 63). Od takrat dalje je bil yun v estetiki, če ne že bolj pomemben, pa vsaj enako pomemben kot qi. Predstavljal je razkritje dovršene umetniške uprizoritve, ki jo spremlja zrela in dovršena osebnost skozi določen umetniški stil. (ibid.)

$\mathrm{V}$ glavnem pa se je smatralo, da qi vključuje yun. Pa vendar so elementi, kot so notranjost, občutek in izraz dejavniki, ki so povezani bolj z yunom kot s qijem. Čeravno obstajajo med qijem in yunom razlike, sta oba koncepta $v$ bistvu neločljiva in recipročna.

Če qi velja za substanco dela, potem yun določa način, na katerega je substanca izražena. $Q i$ je vitalna ustvarjalna sila in yun čudovito in prefinjeno izražen qi. (Wen Fong v Wong 1989, 65)

$\mathrm{V}$ naslednjem podpoglavju se bomo osredotočili na vzajemen odnos qija in yuna in si bolj podrobno ogledali notranjo strukturo besedne zveze qiyun. 


\section{Pomen vaajemnega delovanja qija in yuna - koncept qiyun}

$Q i$ in yun torej oba sodita h konceptom, skozi katera se izraža človeški duh. Zato so qi pogosto imenovali tudi shenqi 神气, medtem ko so yun poimenovali shenyun 神韵. Xu Fuguan meni (Xu 2002, 101), da je qiyun druga narava ljudi (ren de di er ziran 人的第二自然). Lepota umetnosti se lahko dogodi samo znotraj in na osnovi te druge narave, kakršno opisuje že Zhuangzi. Xu izpostavi, da opozarja Zhuangzi na možnost, da ljudje v svoji prvi naravi opazijo oz. prepoznajo drugo. Pri tem gre v glavnem za doseganje enotnosti narave (kozmosa, daota) in človeka. To je stanje preboja, najvišja sfera Zhuangzijeve filozofije. Ta preboj je neke vrste inspirativen preskok, dejanje transformirane človeške zavesti, ki ga spremlja stanje absolutne svobode. Po njem človek vstopi v nek drugi svet oziroma vidi svet iz drugega zornega kota.

Za Xuja je qiyun globlji izraz pojavljanja te druge človeške narave, tj. zlitja oz. enotnosti človeka in narave (dao), ki se kaže v umetniških delih. Hkrati pa meni, da sta oba, tako qi kot yun koncepta, ki neposredno izhajata iz prepoznanja in občudovanja medčloveških odnosov. To prepoznavanje se $\mathrm{v}$ prvi vrsti nanaša na obče človeška občutja in čustva, ki so ljudem skupna. Q $i$ in yun poleg tega jasno izražata lepoto enotnosti duha in zunanje oblike. $V$ tem ne vidi nikakršne povezave z zvoki, zato ponovno poudarja, da prevajati pojem yun z besedo ritem ni ustrezno oziroma pravilno. (Xu 2002, 102)

Zlitje qija in yuna $\mathrm{v}$ en sam koncept (oziroma v binarno kategorijo) se je zgodilo v obdobju Wei Jin, torej v času, v katerem je nastala klasična kitajska estetika kot izjemno kompleksna teorija. Zato nas dejstvo, da je Xie He kot prvi estetski kriterij določil prav koncept qiyun shengdong pravzaprav ne preseneča. Kot bomo videli v nadaljevanju, je Xie He konceptu qi, ki je že sam po sebi izjemno večplasten, namreč dodal še koncept yun, ki ga lahko razumemo tudi kot njegov binarni protipol. V kontekstu Wang Bijeve ontologije benmo 本末 (korenine in vejice), bi lahko razumeli qi kot ben in yun kot mo. V tem smislu bi pomenil qi esenco, yun pa njen izraz. V nadaljevanju bomo videli, ali lahko qiyun dejansko razumemo kot binarno kategorijo.

Ko je Xie He govoril o qiyunu, ga je vedno obravnaval v povezavi z umetniškim delom, ki kot tako nikoli ni določeno objektivno, temveč ga vzpostavi ustvarjalčeva osebnost. To razmerje je bilo obravnavano že v delu Wenxin diaolong 文心雕 龙. (Xu 2002,102) Ustvarjalčeva osebnost oz. njegova notranjost vsebuje yin 阴 (osojnost) in yang 阳(prisojnost) ter gang 刚 (močno in trdo) in rou 柔 ${ }^{15}$ (mehkost

15 Omenjeni koncepti oziroma principi izvirajo iz Knjige premen, katerim je dodan še nebeški in zemeljski qi. 
in nežnost). Vsi štirje principi se prenesejo v umetniško delo in se zlijejo v njem. Yinyang ter gangrou so izraz različnih stanj oz. dinamičnost qija. Qi, o katerem govori Xie He, kaže na upodobitev lepote yanga in ganga v umetniškem delu (yanggang zhi mei 阳刚之美), medtem ko je yun prikaz lepote yina in rouja (yin rou zhi mei 阴柔之美), pri čemer je osnova lepote yuna čistost (qing 清). (Xu 2002, 102) Po Xuju se čistost nanaša na ustvarjalčevo osebnost, ki je prosta sebičnih želja in utilitarističih intencij.

Kljub razliki med konceptoma $q i$ in yun moramo vedeti, da med njima obstaja tudi dinamični odnos. Zato ju nikakor ne moremo absolutno ločiti. Četudi so nekateri v elementu $q i$ videli vodilni princip, pa v bistvu nobeden od obeh polov ne more dominirati ali biti primaren. (Wong 1989, 64) Yin, yang, gang, rou morajo soobstajati znotraj umetniškega dela, pri čemer se ne sme nobenega od njih preveč poudarjati ali zapostavljati. Delo, ki vsebuje preveč qija, lahko rezultira v pomanjkanju rahločutnosti, če pa je prevelik poudarek na yunu, lahko to pripelje do pomanjkanja notranje napetosti in moči. Zato je ohranjanje harmoničnega ravnovesja med qijem in yunom ključno v ustvarjanju umetniškega dela (ibid.) kot tudi v vrednotenju njegove kakovosti in njegovega dometa.

Po drugi strani pa lahko iz zgoraj navedene analize konceptov $q i$ in yun ter iz značaja njunega vzajemnega odnosa sklepamo, da ju je možno razumeti tudi kot binarno kategorijo, v smislu Wang Bijeve ontologije benmo in njegove estetike $y_{i x i a n g^{16}}$. Kot že omenjeno, nastopa $\mathrm{v}$ tej binarni kategoriji $q i$ kot korenina, osnova oziroma esenca (ben), medtem ko je yun prefinjeno dovršen izraz te esence (mo).V tem pogledu yun ne more obstajati brez qija, sama kvaliteta izraza qija pa je tako možna samo in zgolj skozi yun.

Strukturo njunega odnosa vidi tudi Xu Fuguan na podoben način. Vendar opozarja na to, da lahko qi obstaja tudi brez yuna, medtem ko slednji v umetnosti ne more obstajati brez prvega. Po drugi strani pa verjame, da izvira sama ideja qiyuna že iz Zhuangzije filozofije, saj vsebuje mnoge Zhuangzijeve koncepte, kot na primer qing 清 (čistost), $x u$ 虚 (praznino), xuan 玄 (globino) in yuan 远 (odmaknjenost). (Xu 2002, 102)

Kot smo omenili že na začetku, je za Xie Heja prva lastnost, ki določa dovršenost umetniške slike qiyun shengdong. Četudi se ta fraza zelo pogosto zapisuje v celoti, in jo glede na različne kontekste tudi sama opisujem $\mathrm{z}$ izrazom »qiyun je to, kar naredi delo živo«, pa v klasičnih delih ne najdemo podrobnejše oziroma

16 Pri tem gre za xiang 象 (podoba, simol) in yi 意 (pomen, ideja), ki sodita k osrednjim konceptom Wang Bijeve kozmološko - epistemološke teorije, katero smo na kratko opisali v prejšnjem poglavju. Oba omenjena koncepta sta bila namreč prenesena tudi na področje umetnosti oziroma estetike. Njuna fuzija je znana kot yixiang, ki ga je kot prvi zapisal Liu Xie in pomeni estetski ideal. 
nedvoumne razlage glede tega, ali ima shengdong samostojni pomen ali je zgolj učinek qiyuna oziroma izraz njune komplementarnosti.

$\mathrm{V}$ tem kontekstu Xu poudarja, da so teoretiki obdobja Wei Jin, še preden so začeli uporabljati besedo shengdong, v podobnih pomenih pogosto omenjali izraz sheng$q i$ 生气, kar lahko interpretiramo kot premikanje (yuedong 跃动), rojevanje, stvarstvo in proizvajanje qija. Kot kaže, se je ta pojem kasneje transformiral v izraz shengdong ${ }^{17}$. (Xu 2002,108) Celotna struktura izraza qiyun shengdong je enaka, kot struktura sestavljenke qiyun. Medtem ko namreč njen prvi element lahko obstaja brez drugega, obratno ni mogoče ${ }^{18}$ (ibid.).

Po Xu Fuguanu je pomen Xie Hejevega shengdonga v konceptu qiyun shengdong ter vzajemno razmerje med obema terminoma, ki tvorita to sestavljenko, opredeljeno kot:

有气韵, 则有生动矣.

Če je qiyun, potem je tudi shengdong (ibid.).

Ker lahko pojem shengdong razumemo tudi kot dinamiko življenja ali življenjsko silo, in ker je koncept qiyun potemtakem pogoj za vzpostavitev le-te, ima $\mathrm{Xu}$ Fuguan verjetno prav, ko meni, da je qiyun sublimacija življenjske sile, ali - v daoističnem smislu - esenca življenja.

Ker gre pri tem seveda za esenco življenja umetniškega dela, ki je produkt človeške ustvarjalnosti, se pri tem seveda pojavi vprašanje o tem, ali je qiyun stvar kultivacije in izobrazbe ali pa je stvar intuicije, talenta in dovršenega značaja ustvarjalca. Če je qiyun kot estetski kriterij oziroma koncept možno razmeroma jasno definirati, pa obstaja v njem vendarle dimenzija, ki jo je težko zaobjeti z uporabo analitične metode. To, kar je Xu izrazil s frazo druga narava človeka in to, kar je za Zhuangzija stanje popolne osvoboditve duha, je področje, ki se izmika definicijam. Občutja qiyuna v umetniškem delu ne moremo razumeti samo kot lepoto ravnotežja med posameznimi elementi in deli, ki umetniško delo sestavljajo, ampak gre pri njem v prvi vrsti za izraz človeškega občutja. Seveda

17 Shengqi je pravzaprav osnova pojma duha (shen) pri Gu Kaizhiju in prav tako pri Xie Hejevem qiyunu. Shengdong je zunanji izraz občutja, ki se kaže na sliki, shengqi pa je notranje življenje, ki se kaže skozi zunanjost, tj. na umetniškem delu. Iz tega lahko rečemo, da shengdong po svojem notranjem pomenu ne dosega globine pomena shengqi. Shengdong nastane skozi qiyun in je njegov naravni, spontani učinek, kateremu je dodana naracija. Torej se shengdong nanaša izključno na qiyun in nima samostojnega pomena. (Xu 2002,108)

18 Seveda pa se beseda shengdong lahko pojavlja tudi v drugih kontekstih, $\mathrm{v}$ katerih nima nobene povezave s konceptom qiyun, podobno kot se tudi koncept yun $\mathrm{v}$ drugih kontekstih (t.j. izven slikarstva) lahko pojavlja tudi samostojno in neodvisno od koncepta $q i$. 
lahko pri tem govorimo o univerzalnih občutjih, ki jih pravzaprav poznamo vsi ljudje. A vendar je qiyun v glavnem izraz individualne notranjosti posameznika ter njegovega unikatnega, enkratnega in neponovljivega duha, ki na svoj lasten način doživlja notranji in zunanji svet, katerega je sposoben izraziti tudi skozi umetniška dela. $\mathrm{V}$ tem kontekstu Xu meni, da qiyun ni nekaj, čemur se človek lahko priuči skozi izobrazbo in prakso, ampak je prirojen talent, ki se ga ne da in ne more naučiti.

Tako pravi, da je ena največjih zmožnosti umetnika točno $\mathrm{v}$ tem, da lahko v prvi naravi vidi drugo naravo človeka (Xu 2002,119). V kolikšni meri je ta sposobnost prisotna, pa se kaže v tem, ali (in v kolikšni meri) lahko umetnik oz. umetnica znotraj svojega življenja to drugo življenje kreativno sublimira. Qiyun na sliki ali drugem umetniškem delu je izraz njegovega duha. Duh tega dela, torej umetniškega objekta, pa izhaja iz duha ustvarjalca. Transformacija duha umetnikove notranjosti in njegov prenos $v$ ta objekt je nekaj, kar presega vprašanje ustvarjalčeve veščine oziroma tehnike. Qiyun je pravzaprav »od neba dani« talent oziroma neke vrste prirojena dispozicija (tianfu de qizhi 天赋的气质) (ibid.).

Prenesti duha pokrajine pomeni izraziti qiyun pokrajine. Da to ustvarjalec lahko izrazi, mora v prvi vrsti najprej (biti zmožen) transformirati sebe in svoje življenje ter se stopiti v enoto s tem duhom. To pomeni, da mora odstraniti sebične želje, se dvigniti nad njih in izraziti tišino in mirnost, ki sta subjekt in esenca duha umetnosti. $\mathrm{Na}$ ta način lahko v osvetlitvi subjekta svojega umetniškega duha, ki je dejansko v opazovanju lepega, transformira pokrajino v objekt lepote in to je osvetlitev in prikaz duha pokrajine. Ta duh pokrajine gre skozi osvetlitev umetnikove lepote duha. Zato duh pokrajine spontano prodre v lepoto duha kot subjekta umetnosti. $V$ tem se zlijeta skupaj in temu se v kitajski estetiki pravi »iskanje notranje oddaljene pokrajine« (Xu 2002, 120)

Pri tem prenosu, ki je torej qiyun, pa nikakor ne gre za imitacijo (mimesis) pokrajine oziroma narave na sliki, temveč bolj za prenos duha pokrajine skozi lastnega duha, ki se razkrije skozi veščino (suishou xiechu, jiervei shanshui chuanshen 随手写 出, 皆为山水传伸, ibid.). Izvor tega prenosa torej ni v veščini, ampak izvira iz esence duha umetnosti, ki se pojavi skozi transcendenco in transformiranje življenja ustvarjalca oz. ustvarjalke. Iz tega razloga je tudi umetnost sama po sebi zmožnost transformiranja in transcendiranja človeka.

Predpogoj za prenos duha življenja (lastne notranjosti ali zunanje narave) v fizično podobo umetniškega dela, t.j. predpogoj za realizacijo qiyuna je torej doseganje izpraznjene in umirjene srčne zavesti (xin 心) in stanja absolutne svobode, o kateri govori Zhuangzi v svoji filozofiji »Svobodnega in lahkotnega 
lebdenja« (xiaoyao you 逍遥游 ${ }^{19}$. Zato ustvarjalni vnos qiyuna v umetniško delo tudi pri njem izvira iz očiščenja oziroma postenja srčne zavesti (xinzhai 心斋).

Če želi umetnik v svojem delu doseči qiyun, mora seveda slediti določeni strukturi, ki se lahko pokaže skozi njegovo obvladanje tehnike. Ampak qiyun, ki se kaže skozi objekt, dejansko izvira iz lastnega truda samokultivacije, ki iz srčne zavesti očisti »blato in kaos«. V zlitju duha (umetnika in umetniškega objekta) pride do osvoboditve. Prav tovrstna samo - kultivacija, tj. kultivacija lastnega značaja in posledična zmožnost osvoboditve duha je predstavljala tisto osnovo vseh umetniških veščin, ki je bila potrebna za to, da si lahko na Kitajskem veljal za velikega umetnika, in da si lahko to tudi dejansko postal. Imeti ali ne imeti tovrstno osnovo je pravzaprav ločnica, ki ločuje mojstre od tistih, ki zgolj obvladajo veščino.

\section{Kritična evalvacija Xu Fuguanove interpretacije koncepta qiyun shengdong}

V zadnjem delu članka bomo podali kritično oceno Xujeve interpretacije tega pomembnega koncepta klasične kitajske estetike. Pri tem bom podrobneje osvetlili predvsem dve stališči, ki se kot rdeča nit vlečeta skozi vse Xujeve razprave o omenjenem konceptu. Pri prvem gre za Xu Fuguanovo stališče o avtohtonosti tega koncepta oziroma za njegovo negacijo teorij, po katerih naj bi bil ta koncept (skupaj z vrsto drugih) prevzet iz staroindijske umetnostne teorije Sadanga (Šst vej). Drugo stališče je stališče o tem, da konceptov yun in qiyun v zahodne jezike nikakor ne moremo prevajati s pojmi ritem, ritmičen ali ritmičnost. Kritična evalvacija obeh zgoraj navedenih stališč v sodobnem kontekstu je pomembna v okviru ponovnega ovrednotenja klasičnih konfucijanskih in daoističnih elementov v sestavi klasične kitajske umetnostne teorije oziroma estetike in tudi za vključevanje medkulturnih razsežnosti v diskurze tega področja.

\section{Kritična evalvacija teze o prevzemu koncepta qiyun shengdong iz indijske teorije slikarstva}

Victor H. Mair v članku Xie He's "Six Laws " of Painting and their Indian Parallels $(2004,81)$ skozi lingvistično in historično analizo dokazuje vpliv indijske teorije slikarstva, zapisane v delu Sadanga ( ̌́ est vej) na Xie Hejevih Šst zakonitosti. Obe

19 To ni samo Xu Fuguanovo mnenje, temveč gre pri tem za stališče, ki so ga zastopali tudi mnogi tradicionalni teoretiki. Tako je na primer že Guo Ruoxu 郭若虚, znan umetnostni kritik iz 11 . stoletja, zapisal: »V vseh umetniških slikah je esenca qiyuna v lebdenju srčne zavesti.« (凡画, 气韵 本乎游心) (Zhongguo hualun 2017, s.p.). 
deli sta nastali približno $\mathrm{v}$ istem času ${ }^{20}$ in sta imeli v enaki meri izjemen vpliv na slikarstvo v obeh kulturah. Obe kulturi sta bili takrat v zelo tesnih stikih zaradi budizma, ki je globoko vplival na kitajsko kulturo prav v obdobju Wei Jin. Mair meni, da obstaja velika možnost, da je Xie He v svojih teorijah pravzaprav prevzel model in vsebino indijske Sadange. To dokazuje na podlagi dejstva, da antični kitajski teksti, torej besedila, ki so nastala pred prihodom budizma, ne vsebujejo numeričnih naštevanj (prvo, drugo, tretje itd.), ki jih najdemo pri Xie Hejevih šestih zakonitostih. Mair omeni, da večina kitajskih akademikov zastopa nasprotno mnenje $\mathrm{z}$ argumentom, da sta prvi dve Xie Hejevi zakonitosti vidni že v prejšnjih produktih avtentične kitajske tradicionalne estetike slikarstva ${ }^{21}$. (ibid., 116)

Xu Fuguan je podobno idejo o podobnosti in prevzemu Sadange pri Xie Hejevih Šstih zakonitostih zasledil v delu Indian Painting avtorja Percyja Browna iz leta 1920, ki pa jo absolutno zanika $(2002,121)$. Xu namreč meni, da je podobnost zgolj plod naključja, in da izvora Xie Hejevih Šestib zakonitosti nikakor ne gre pripisovati indijski Sadangi, kjub temu, da naj bi bil sam izvor slednjega dela kar nekaj stoletij starejši. Xu to dokazuje tudi na podlagi dejstva, da v Sadangi najdemo samo tri od šestih zakonitosti, ki jih poda Xie He, in ki naj bi korespondirali s Sadanginim konceptom. Eden od teh treh konceptov naj bi bil tudi qiyun shengdong, za katerega $\mathrm{Xu}$ pravi, da ima dosti globlji pomen kot njegov formalni ekvivalent iz Sadange.

Kljub izjemni analizi in novim dokazom, ki jih poda Victor H. Mair, je glede numeričnega oštevilčevanja, ki naj bi bil prenesen iz Indije in katerega naj bi Xie He prenesel na svojih šest zakonitosti slikarstva, pomisliti še na možnost, da je Xie He pri oštevilčevanju zakonitosti prevzel obliko heksagrama iz Knjigepremen. Slednja je bila namreč v obdobju Wei Jin znotraj neodaoistične šole Xuanxue zelo $\mathrm{v}$ ospredju. Glede na to, da je v konceptu qiyun shengdong zajeta manifestacija dinamičnega odnosa yinyang in gangrou, ter nebeškega in zemeljskega qija, ki jo poznamo prav iz Knjige premen, je morda potrebno upoštevati tudi možnost, da se je Xie He ravno na tej osnovi odločil za tovrstno šestdelno klasifikacijo. Po drugi strani pa šestdelno klasifikacijo najdemo tudi v Knjigi pesmi (11. do 7. st. pr. št.), kjer so posamezne oblike in vsebine pesmi razdeljene kronološko. Iz obojega lahko sklepamo, da je število šest simboliziralo neke vrste kozmično in strukturno urejenost. Seveda je to predmet nadaljnjih premislekov in raziskav ${ }^{22}$.

20 Pri tem pa je treba omeniti, da naj bi imela sama Sadanga svoj izvor v Vedah, ki pa je besedilo iz osmega stoletja pr. n. št.

21 Vsekakor ne moremo mimo dejstva, da sta si obe deli po vsebini zelo podobni. Na tem mestu ne bomo navajali posameznih delov Sadange, za podrobno razlago glej Mair (2004).

22 Poleg tega pa moramo vzeti v obzir tudi dejstvo, da so kitajski teoretiki v idejnih konceptih, ki so prihajali iz drugih kultur, vedno poskusili najti ekvivalentni ali vsaj podobni idejni koncept znotraj svoje lastne kulture. 
Xu Fuguan je, kot smo videli zgoraj, nazorno pokazal, da je qiyun tradicionalni estetski koncept, ki je precej starejši od njegove prezentacije v delu Xie Heja. Sicer je teoretično možno, da se je Xie He dejansko srečal z indijsko teorijo slikarstva, in da je Sadango ter njeno strukturo prenesel v kitajski okvir, kot trdi Victor H. Mair; vendar moramo biti pri tovrstnih trditvah previdni, saj so konec koncev nedokazljive in zato dvomljive. Kot smo videli v gornjih poglavjih, nam prav Xu Fuguan v svojem delu Esenca duba kitajske umetnosti nudi tudi obilo težko ovrgljivih dokazov za tezo, po kateri so osnove estetike, ki je nastala pod Xie Hejevim čopičem, daoistične narave in vsebujejo veliko elementov najstarejših kitajskih klasikov iz obdobja avtohtone, t.j. predbudistične tradicije.

\section{Problem prevajanja koncepta qiyun shengdong v indoevropske jezike}

Kot smo videli v uvodu članka, se Xu ne strinja s prevodom qiyuna v smislu ritmičnosti. Na tovrsten prevod Xu naleti v delih Chinese Art avtorja Stephena Woottona Bushella iz leta 1904, Painting in the Far East avtorja Laurenca Binyona iz leta 1908 in The meaning of Art Herberta Reada iz leta 1931. Pri tem Xu problematizira sam prevod yuna kot ritmičnost, kot tudi to, da so ti tuji teoretiki ta prevod prenesli na celotni koncept qiyun. Pri tem opozori, da se v delu Shishuo xinyu 世 说新语 (Nov opis zgodb sveta), zbirki dialogov in zgodb iz pozne dinastije Han (25-220) do Severnih in Južnih dinastij (420-589) izpod peresa Liu Yiqinga 刘义 庆 (403-444), qi in yun nista uporabljala skupaj, temveč ločeno. Xu iz omenjenega dela navede frazo, v kateri se $q i$ in yun navajata ločeno $v$ frazi fengqi yundu 风气韵 度, pri čemer naj bi bil izraz fengqi 风气 ena beseda, ki je pomenila atmosfero oz. vzdušje, yundu 韵度 pa druga, ki je pomenila stopnjo oziroma intenzivnost yuna. Do Xie Heja so po Xuju slikarji in teoretiki qi in yun torej jasno ločevali med seboj. (Xu 2002, 94)

Xu precej strogo zavrača Readovo postavko, po kateri lahko skozi harmonično urejenost potez na sliki občutimo ritem. Pravi, da je to izključno stvar človeške domišljije, subjektivnega občutka in metaforičnosti ter da qiyun ni ritmičen $\mathrm{v}$ tem smislu. Seveda gre pri qiyunu tudi za enotno harmonijo potez, ampak ta ne more ustvariti qiyun shengdonga. Poleg tega izpostavi $\mathrm{Xu}$, da naj bi bila razlika med zahodnim in kitajskim slikarstvom $\mathrm{v}$ tem, da iščejo zahodni slikarji to, kar je v potezah samih, medtem zasledujejo kitajski slikarji tisto, kar je onkraj potez. V zahodnem slikarstvu je ritem tista presežnost, ki se izrazi skozi harmoničnost potez. Seveda se kitajski slikarji prav tako osredotočajo na poteze, vendar je končni cilj njihovega ustvarjalnega procesa v tem, da slikar poteze pozabi, se osvobodi iz omejenosti njihovih spon in ter izrazi kreativnost in svobodo svojega duha. Iz tega razloga se za Xuja qiyuna 
(ali yuna) nikakor ne sme prevajati kot ritem ali ritmičnost. (Xu 2002, 98) Glede na to, da pa je po drugi strani ritem izpostavil kot nekaj, kar je vezano izključno na zaporedja zvokov (ibid., 99), se ob tem lahko vprašamo tudi po tem, ali je Xu dejansko pravilno razumel angleški pojem rhythm, saj gre pri tem za izraz, ki zdaleč presega konotacijo razmeroma hitrih in ponavljajočih se zaporedij zvokov v glasbi. $V$ članku smo poleg tega navedli tudi Xujev citat, v katerem trdi, da naj bi bil prefinjen yun najti v naravi (ziran you yayun). Iz tega navedka lahko yun (in tudi qiyun) dejansko razumemo kot ritem, ki se kaže skozi ponavljajoče se procese v naravi. Narava (ali nebeški dao) imata namreč nek svoj ritem, ki mu sledi in ga hkrati ustvarja. Če prenesemo tak pomen yuna (ki pa seveda ni njegov edini pomen) na področje umetnosti in na konkretne umetniške stvaritve, ga lahko pravzaprav dejansko razumemo tudi na tak način. Če je estetski ideal kitajskega slikarstva v obdobju Wei Jin in kasneje, v krajinskem slikarstvu dinastije Song, prenos duha narave na kar najbolj neposreden način (pri čemer je potrebno imeti v mislih, da pri kitajskem slikarstvu ne gre za mimesis), gre pri tem nujno tudi za upodobitev ritmov, ki se v naravi dejansko dogajajo. Ta ritem se ustvarja skozi poteze ali v primeru poezije skozi rimo, ritem in zven (ton) posameznih besed.

Vsekakor se lahko strinjam s Xujem, da ritem ali ritmičnost ni ustrezen prevod koncepta yun oz. qiyun, ker ne pokriva vseh njegovih pomenskih dimenzij, vendar pa hkrati menim, da je ritem tudi ena izmed njegovih pomembnih in osrednjih pomenskih konotacij.

Kljub temu pa Xujeva analiza in interpretacija koncepta qiyun shengdong jasno pokaže, da je omenjeni koncept pravzaprav zelo težko, če že ne kar nemogoče prevesti v katerikoli indoevropski jezik, ki bi lahko ustrezno izrazil njegov kompleksen pomen. Seveda pa bodo šele nadaljnje raziskave lahko pokazale, ali bo najbolj smotrno, ta izraz prevzeti in ga uporabljati v izvirniku kot terminus technicus, ali pa se bo disciplina sinološke estetike vendarle odločila za nek splošni in kolikor toliko verodostojen prevod tega pomembnega pojma.

\section{Viri in literatura}

Brown, Percy. 1918. Indian Painting. Oxford University Press. London. Binyon, Laurence. 1908. Painting in the Far East. Edward Arnold. London. Cai, Zong-qi. 2004. "A Historical Overview of Six Dynasties Aesthetics." V Chinese Aesthetics. The Ordering of Literature, the Arts, and the Universe in the Six Dynasties, uredil Zong-qi Cai, 1-28. Honolulu: University of Hawai'i Press.

Cao, $\mathrm{Pi}$ 曹丕. s.d. Dian lun lunwen 典论伦文 (Razprave o literaturi). Dostop 10.3.2017. http://chincenter.fg.tp.edu.tw/ learning/classical-01.php?id=142. 
Guanzi 管子. s.d. V Chinese Text Project. Pre-Qin and Han. Dostop 10.3.2017. http://ctext.org/guanzi/nei-ye.

Li, Zehou. 2003. Meixue san shu 美学三书 (Tri knjige o estetiki). Tianjin shehui kexue yuan chubanshe. Tianjin.

Liu, Xie 刘劦思. s.d. Wenxin diaolong 文心雕龙 (Srčna zavest literature in rezbarjenje zmaja). V Chinese Text Project. Post Han. Dostop 10.3.2017. http://ctext.org/ wenxin-diaolong.

Mair, H. Victor. 2004. "Xie He's 'Six Laws' of painting and their Indian Parallels." V Chinese Aesthetics. The Ordering of Literature, the Arts, and the Universe in the Six Dynasties, uredil Zong-qi Cai, 81-122. Honolulu: University of Hawai'i Press.

Read, Herbert. 1931. The Meaning of Art. Hardmontsworth. Middlesex.

Rošker, Jana S. 2005. Iskanje poti: Spoznavna teorija v kitajski tradiciji. 1 del. Od protoznanstvenih klasikov do neokonfucijanstva dinastije Song. Ljubljana: Razprave FF. Znanstveni inštitut FF.

—. 2014. "The Philosophical Sinification of Modernity and the Modern Confucian Paradigm of Immanent Transcendence." Asian Studies 2 (1): 67-81.

—. 2017a. "Chinese Modernization and the Sinification of Marxism through the Lens of Li Zehou's Philosophy." Asian Philosophy 27 (1): 1469-2961. DOI 10.1080/09552367. 2017.1290602.

—. 2017b. "The Concept of Q $i$ in Chinese Philosophy - a Vital Force of Cosmic and Human Breath." V Atmospheres of Breathing: The Respiratory Questions of Philosophy, uredila Lenart Škof in Petri Berndtson. New York: Suny. (v tisku) Vampelj Suhadolnik, Nataša. 2013. “Chen Shizeng's 'Theory of Subjectivity': the Influence of Chinese Literati Painting on the Artistic Search for Western Modern-'isms' in the Republican Era." Dve domovini 37: 93-102.

Wang, Qingwei. 2004. "Qiyun” and Poetic Thinking of the Chinese Classical Aesthetics. Dostop 26.2.2017. http://en.cnki.com.cn/Article_en/CJFDTotal-YTXS200402011.htm.

Wong, Ching-Ping. 1989. The Manifestation of Chinese Philosophy and Aesthetics in the Performance of the Pipa Music. Kingston: Kingston Polytechinc.

Wotton Bushell, Stephen. 1904. Chinese Art. Wyman and Sons. London.

Xie, He 谢赫. s.d. Gu bua pinlu 古画品录 (Zapisi o antičnem slikarstou). Gu shi wen wang. www.gushiwen.org. Dostop 10.03.2017. http://so.gushiwen.org/ guwen/book_160.aspx.

Xu, Fuguan 徐复观. 2002. Zhongguo yishu jingshen 中国艺术精神 (Esenca duha kitajske umetnosti). Xu Fuguan wenji. Wuhan: Hubei renmin chubanshe.

Zhongguo hualun 中国画论 (Razprave o kitajskem slikarstvu). 2017. Dostop 10.03.2017. http://www.zsbeike.com/cd/42128160.html. 